\title{
MARCUSE Y EL "DERECHO UNIDIMENSIONAL"
}

1

No cabe duda que Herbert Marcuse es una de las personalidades más discutidas en el mundo actualmente y cuyas ideas han tenido intensa repercusión sobre algunos de los más importantes acontecimientos político-sociales de los últimos años. $Y$ resulta verdaderamente desconcertante que una persona como Marcuse, sin militancia política desde el año 1919, profesor universitario de 70 años de edad, amante de la naturaleza, miembro del Comité Zoológico de San Diego y enemigo del ruido, sea precisamente quien haya desencadenado movimientos politicos de una beligerancia verdaderamente inusitada. Dedicado a la enseñanza en la Universidad de San Diego, California, Estados Unidos, todos sus contactos han sido desde hace mucho tiempo sólo con el medio universitario. De un lado a través de sus clases, del trato diario con los estudiantes; de otro lado, a través de sus obras, de lectura difícil, de ninguna manera destinadas al político medio o al hombre de la calle sino a un público marcadamente intelectual. Sin embargo, estas circunstancias son en sí mismas reveladoras: si un universitario es capaz de impartir tal impulso político, es que la Universidad misma tiene un rol político que cumplir dentro de la coyuntura presente. Ahora más que en otras épocas, la Universidad se ha convertido en la conciencia de la sociedad, en el interlocutor lúcido que pone en cuestión las bases mismas de la organización social y postula la liberación de la imaginación creadora para construir una sociedad nueva, un hombre nuevo, para realizar aquellas aspiraciones sociales que, en muchos casos, habían sido confinadas en el campo de lo utópico o lo fantástico. Y Marcuse es precisamente el teórico de esta Universidad crítica y de la legitimación de la utopía. Sin embargo, Marcuse no nos propone un "modelo" de sociedad, no nos dibuja una sociedad "ideal"; simplemente, nos invita a dar un "salto al más allá", a franquear todos los límites explicitando las tendencias ocultas, los anhelos reprimidos, los valores menospreciados, que corresponden a una sociedad futura y que ya están presentes en la realidad actual pero que requieren ser puestos de manifiesto para desarrollar su fuerza negativa. Esta es una tarea en gran parte intelectual, es decir, universitaria.

Ahora bien, el pensamiento de Marcuse plantea una problemática bastante ajena al Derecho, al menos de primera impresión. Entre sus obras fundamentales st encuentra una tesis filosófica sobre Hegel, unos artículos sobre el tema de la sociedad totalitaria - que aparecerá muchas veces en sus trabajos- y sobre filosofía de la cultura (1), un ensayo de interpretación social de las ideas de Freud (2), un estudio del marxismo soviético (3), una denuncia del totalitarismo sutil de la sociedad llamada libre (4). En algunas de estas obras advertimos la presencia de consideraciones juridicas. Sin embargo, los planteamientos expuestos en ellas estén decididamente centrados en una preocupación social: Marcuse pretende sentar las bases de una filosofía revolucionaria sobre la sociedad; de ninguna manera, trazar una teoría del derecho positivo. Por consiguiente, si creemos que los juristas sólo deben ocuparse de "establecer lo que es Derecho y cómo es", si consideramos que la reflexión jurídica "no intenta de ninguna manera decir cómo el Derecho debería o debe ser" porque "entiende ser ciencia

1 Marcuse, Herbert: Cultura y sociedad. $2^{\mathrm{a}}$ ed. Buenos Aires, 1968, Editorial Sur.

2 Marcuse, Herbert: Eros y Civilización. Una investigación filosófica sobre Freud. México, 1965. Editorial Joaquín Mortiz.

3 Marcuse, Herbert: Le marxisme soviétique. Essai d' analyse critique. Francia, 1963. Editions Gallimard.

4 Marcuse, Herbert: L'homme unidimensionnel. París, 1968. Les éditions de minuit. 
del Derecho y no política jurídica" (5), en tal caso, resulta ocioso que un jurista tome en cuenta a Marcuse y esta revista no tiene razón alguna de incluir un artículo sobre sus ideas. En efecto, cabe postular una división del trabajo tajante y radical entre aquellos que crean la norma juridica y pretenden justificarla en base a consideraciones de todo tipo que se reúnen bajo el nombre de "justicia" y aquellos otros que se limitan a la aplicación de la norma jurídica y la justifican únicamente por su existencia objetiva dentro de un sistema de normas, por su positividad. Según Kelsen, solamente estos últimos son los juristas: la ciencia juridica debe liberarse de la psicología, soc:ología, ética y teoría política con las que estaba confundida, para convertirse en una teoria "pura" del Derecho. (6). Esto no significa que la ciencia juridica desconozca la existencia de la justicia sino únicamente la relega al campo de lo subjetivo (7), contradictorio y relativo (8), Por consiguiente, un estudio científico del Derecho debe excluir el análisis de la justicia de la norma para remitirse a un criterio de validez "objetiva" que no puede ser otro que su conformidad con una norma superior y así sucesivamente hasta alcanzar una "Constitución hipotética" (Grundnorm) que prescribe como artículo único el respeto a las normas objetivamente válidas, es decir, positivamente vigentes (9). En esta forma, el Derecho queda reducido a una ciencia formal que se niega a sí misma la labor de evaluación del contenido material de las normas. Esta es la corriente que se autodenomina "positivista": en este sentido, el positivismo jurídico "rehusa evaluar el derecho positivo. No se considera, en tanto que ciencia, como obligado a ninguna otra cosa ni a nada más que a coger el derecho positivo en su esencia y a comprenderlo por un análisis de su estructura. Rechaza en particular toda idea de servir a cualquier interés político proporcionándole las "ideologías" gracias a las cuales el orden social existente sería legitimado o, por el contrario, descalificado" (10), En esta forma, el positivismo

5 Kelsen, Hans: Théorie Pure du Droit. Traduction française de la 2e. édition de la Reine Rechtslehre. París, 1962. Dalloz, pág. 1.

6 Ibid. pág. 1.

7 Kelsen, Hans: Justicia y Derecho Natural in Crítica al Derecho Natural, obra colectiva. Madrid, 1966. Ed. Taurus, pág. 39.

8 Ibid. pág. 101.

9 Kelsen, Hans: Théorie Pure du Droit, ed. cit. pág. 266.

10 Ibid. pág. 148. jurídico establece las bases de una ciencia "unidimensional" del Derecho porque ha renunciado a la crítica adoptando como única dimensićn el sometimiento al orden establecido cualquiera que sea.

Para Marcuse, este planteamiento "purista" es inaceptable respecto de cualquier ciencia. La realidad no está constituida por un conjunto de formas abstractas e independientes sino por una totalidad concreta que se manifiesta a través de cada uno de sus elementos y que no permite el estudio de éstos como entidades separadas. La ciencia positivista pretende disociar la materia compleja de lo real; pero, en esta forma, lejos de lograr una mayor objetividad de conocimiento, subjetiviza su apreciación al descartar cierios aspectos de la realidad excluyendo de su estudio todo lo que no responda a sus criterios. (11). La ciencia "pura" conduce únicamente a un conocimiento abstracto -por consiguiente, en cierta forma arbitrario- que aspira a aislar las cosas del sentido impartido en ellas por los hombres. Sin embargo, tal aspiración es imposible porque todo objeto es objeto para el hombre $y$, en consecuencia, aparece ya cargado del sentido que le ha proporcionado la activi dad anterior del hombre y siempre se encuentra abierto a recibir nuevos sentidos: una dimensión esencial de la cosa - cualquiera que ella sea, norma jurídica, motor eléctrico o espacio interplanetario- es la de constituir un receptáculo de fines humanos. $\mathrm{Y}$, por su parte, el hombre no es nunca meramente observador sino que también es autor de su historia en cada uno de sus actos, incluyendo la labor científica. Es así como todo objeto aspira a un sentido y todo acto humano provoca un sentido, consciente 0 inconscientemente. El hombre es como un rey Midas que todo lo que toca lo convierte en humano. $Y$ quien dice humano dice histórico: "humanizar" un objeto es situario históricamente dentro de una realidad humana. Así la historia se vuelve sobre sí misma y engloba al historiador, la realidad científica aparece organizada por los valores e intereses subyacentes en el horizonte histórico del científico, el Derecho vehicula la concepción social del jurista y éste transforma el Derecho al estudiarlo, en virtud de la creación, sistematización e interpretación de las normas que constituyen el objeto de su ciencia. No existe, pues, una ciencia neutra, un Derecho "puro'.

11 Marcuse, Herbert: L'homme unidimensionnel, ed. cit. pág. 189. 
No cabe duda que el método científico de hipótesis y hechos que se justifican y establecen recíprocamente obtiene una objetividad; Marcuse no pretende negar la validez de la ciencia (12). Pero es una objetividad histórica porque si estas hipótesis se desarrollaran en un contexto experimental diferente, establecerian hechos esencialmente diferentes: el sistema de hipótesis -el sistema justificatorio de las normas por la inmediatamente superior dentro de la teoria positivista del Derecho- no funciona en el vacío sino en el interior de otro sistema que es el universo de fines preestablecidos en la práctica histórica del hombre (13). El problema del positivismo es que neutraliza el contenido histórico de la racionalidad al considerar que un determinado estado del pensamiento $-y$ de la sociedad, en el caso del positivismo sociológico- se identifican con lo racional. Pero este aspecto histórico, dice Marcuse, no es algo accesorio sino un elemento constitutivo del pensamiento (14). Por eso cuando Kelsen acepta las posibilidades de variación del contenido de las reglas jurídicas pero relega este contenido a un plano anticientífico y pretende sentar las bases de un conocimiento racional limitado al aspecto meramente formal de la norma, incurre en el error de crear una teoria abstracta - por consiguiente, inutilizable para medir lo real- $y$, en todo caso, supeditada también a la concepción históricamente dominante de los valores sociales. El positivismo crea asi un mundo reducido, encerrado dentro de sus propios criterios, que rechaza toda intervención extraña acusándola de metafísica (15). Y el problema es aún más serio: Marcuse denuncia que estas concepciones "puras" no son al menos "inofensivas" sino que contribuyen a escamotear el debate sobre los fines asegurando asi la permanencia de los valores establecidos. Marcuse señala que todos los dias se lleva a cabo a través de múltiples medios (que van desde la comunicación de masas hasta la psiquiatria) verdaderas sesiones de magia o brujería que transforman exteriormente lo irracional en racional y que encandilan con éxitos aparentemente racionales que encubren la irracionalidad del conjunto del sistema (16). $\mathrm{Y}$, en verdad, nadie que haya leído a Kelsen se ha librado de la atracción deslumbrante que surge de la fuerza de sus razona-

12 Ibid. págs. $189-90$.

13 Ibid. pág. 191.

14 Ibid. pág. 249.

15 Ibid. pág. 205.

16 Ibid. pág. 213. mientos lógicos, de la sutileza de sus distinciones, del brillo polémico de su argumentación; sin embargo, esta teoria "pura", esa lógica jurídica descarnada, puede justificar todos los crímenes que ha cometido la human:dad en nombre del Derecho: dejando de lado su contenido, la ciencia jurídica positivista se limita a examinar si la ley nazi que enviaba a los judíos a los campos de concentración era "objetivamente" válida en función de la norma superior. Es posible que los abogados de las grandes Compañias alemanas encargados de estudiar los contratos que celebraban esas firmas industriales con las autoridades de los campos de Auschwitz, Dachau, etc. para la utilización intensiva de la mano de obra judía, se sentían interiormente tranquilos porque el ejercicio profesional del Derecho "puro" no les permitía pronunciarse sobre el contenido que, según Kelsen, debe dejarse a los políticos, psicólogos, economistas, etc. $Y$, en esta forma, gracias a esta "neutralidad técnica", todo hombre es liberado de cualquier sentimiento de culpa, la dominación se hace más impersonal, la irracionalidad de las metas queda camuflada bajo una insospechable racionalidad técnica y el mundo se transforma en la substancia de una "administración total" que somete a los administradores mismos (17).

Frente a la concepción positivista, Marcuse propone una ciencia lúcida, plenamente consciente de su compromiso con ciertos fines preestablecidos históricamente. En realidad, dice Marcuse, la técnica es un universo de instrumentalidades que lleva implícitas ciertas metas $u$ objetivos. Por eso, no podemos decir que la técnica es neutra sino, por el contrario, refleja siempre un proyecto político (18). Esto nos lleva a que es fundamental reconocer y evaluar este aspecto político que an:ma tanto la técnica como la ciencia y aceptar que la pretensión de realizar una ciencia "pura" no nos permite coger la riqueza de lo real concreto $y$, en muchos casos, resulta simplemente un servicio a la represión establecida. Ahora bien, si toda ciencia, toda técnica, desenvuelve su actividad dentro de la línea de opciones que determina la praxis social del hombre, con mayor razón aún aquellas que están más próximas a ella, que constituyen sus manifestaciones más directas: las ciencias sociales. $Y$, entre ellas, resulta indudable que las ciencias normativas - como es el caso del Derecho- se encuentran aún más estrechamente vinculadas a un univer-

17 Ibid. pág. 192.

18 Ibid. págs. $21-22$. 
so de valores sociales. ¿Cómo puede, entonces, intentarse un estudio del Derecho como mera forma, independiente de su contenido social?

II

Nos encontramos, entonces, frente a un Derecho "politizado", por asi decirlo, frente a una ciencia jurídica "comprometida" con la sociedad. El jurista no puede limitarse al estudio formal de las normas despreocupándose de su instrumentalidad social concreta sino que una apreciación lúcida de su función propia lo lleva a abrirse hacia lo social para ajustarlo a un sistema de valores. Evidentemente, ello no significa tampoco la vuelta hacia una concepción romántica según la cual los hombres de Derecho estarían en una posición privilegiada respecto de las otras ciencias sociales porque su formación les permitiría comprender mejor la idea eterna de Justicia. El Derecho es sólo una de las tantas formas en que se manifiesta la praxis social. La especificidad de la ciencia jurídica no es el resultado de una sectorización de la realidad social en compartimientos estancos - sean éstos las leyes positivas o las exigencias de la Justicia- sino que obedece simplemente a un punto de vista particular, a una diferente aproximación al todo social; e incluso este punto de vista o aproximación distinta está condicionado por el todo social mismo que lo engloba en su desarrollo histórico.

Sin embargo, esta concepción del Derecho nos conduce a un problema de dificil solución. Hemos visto que el jurista está obligado a trascender el campo de la positividad legal o Derecho positivo vigente para reubicar la ley dentro del contexto social. Pero, a su vez, si comprendemos la sociedad como un movimiento, si insertamos la estructura social como un momento de una historia humana, entonces es preciso trascender también la positividad sociológica hacia nuevas formas de organización social. $Y$ esto supone evaluar los posibles proyectos, escoger entre las anticipaciones, decidir el sentido de la historia.

¿Qué criterios adoptaremos para ello? Una primera respuesta puede formularse desde el pensamiento clásico: cabe suponer que el hombre es capaz de comprender ciertos valores eternos e inmutables que nos señalan el rumbo adecuado para llegar a la perfección. Esta posición supone acoger en mayor o menor grado un "modelo de sociedad" a-histórico, intemporal, porque constituye la guía de todos los tiempos. Marcuse rechaza esta solución. Reconoce que al formular un "deber-ser" opuesto al "ser" actual, esta concepción clásica tiene la virtualidad de poner en cuestión la sociedad existente y liberar un cierto dinamismo trascendente. Pero considera que el pensamiento procede de condiciones históricas y que, en consecuencia, está cerrado a todo análisis que aparte del tiempo al objeto estudiado: el intento de encontrar un mundo de valores absolutos equivale a tratar de comprender cómo se ve la Tierra desde otra galaxia olvidando que incluso esa otra galaxia ha sido comprendida previamente desde el punto de vista terrestre. Además, el hombre es esencialmente libertad $y$, por consiguiente, va permanentemente remodelando su contorno. Pero, entonces, si no podemos salirnos de la historia para encontrar fuera de ella su sentido, ¿qué base objetiva puede existir para evaluar las diferentes eventualidades que proyecta el pensamiento? ¿No cabe pensar que no hay ningún criterio objetivo y que, consecuentemente, todo es subjetivo y relativo? Con esta duda nace el historicismo (19). Y es también este historicismo en cuanto al contenido material de la norma que encontramos en la base del pensamiento kelseniano y que lo lleva a buscar lo objetivo y lo absoluto en las formas puras. El positivismo, sea éste jurídico o sociológico, tiene su origen en una concepción relativista que impide emitir juicios de valor. Por el contrario, Marcuse considera que atribuirle un contenido histórico al pensamiento no implica una negación de la objetividad; simplemente, esta objetividad se da sólo en el interior de un horizonte histórico determinado. (20).

Ahora bien, si es posible encontrar valores "objetivamente válidos" que nos permitan juzgar la realidad establecida - no sólo jurídica sino social en general- e incluso sugerir nuevas formas de organización social, ¿qué criterios nos permitirán descubrir tales valores frente a una sociedad determinada? En otras palabras, ¿cómo encontraremos en concreto los valores objetivamente válidos para nuestra época? Marcuse propone fundamentalmente dos reglas, que actúan como condiciones recíprocas. En primer lugar, que la anticipación propuesta sea posible de realizarse atendiendo al nivel logrado por la cultura material e intelectual; es decir, el proyecto valioso que trasciende la realidad establecida debe ser históricamente posible. (21). En esta forma, la utopía absoluta queda descartada al igual que todo aquello

19 Ibid. pág. 241.

20 Ibid. pág. 242.

21 Ibid. págs. 244-5, también págs. 17 y 18. 
que no sea factible de situar en el tiempo. Sin embargo, esto no significa que la anticipación no pueda planiearse a muy largo plazo a condición de que pueda razonablemente proponerse las etapas para lograrla; y siempre habrá que tener en cuenta que esta anticipación se produce desde nuestro horizonte histórico y que, en consecuencia, es previsible que varie notablemente al desplazarse los umbrales de dicho horizonte. Es sólo en este sentido que Marcuse ha puesto mucho énfasis en el valor crítico de las utopias, pues permiten poner en cuestión en forma global y radical la realidad establecida (22). En segundo lugar, Marcuse propone como criterio de valor que el proyecto $o$ anticipación trascendente al orden jurídico o social existente deba probar que su racionalidad es superior a la de la totalidad establecida. Este planteamiento conlleva a su vez la adopción de criterios de racionalidad; y Marcuse sugiere los siguientes: (a) que aquella eventualidad que se plantea como valor ofrezca la perspectiva de preservar y mejorar las realizaciones productivas de la civilización; (b) que el proyecto o anticipación defina la totalidad establecida en su estructura auténtica, en sus tendencias fundamentales $y$ en sus relaciones; $y$ (c) que su realización ofrezca mayores posibilidades de éxito para la pacificación de la existencia, en el interior de un marco institucional que favorezca mejor el desarrollo de las necesidades y de las facultades humanas. (23). En suma, lo que se trata es de crear una sociedad que permita satisfacer las necesidades bésicas y en la que el hombre se encuentre liberado de la culpa y del temor (24); pacificar la existencia quiere decir "suprimir la guerra, la crueldad, la brutalidad, la estupidez, la fealdad, la opresión" (25). Para hacer más gráfica esta pretensión de crear una sociedad que permita la realización más plena del hombre integralmente considerado, dice Marcuse, citando a Baudelaire, que "La verdadera

22 Marcuse, Herbert: Eros y Civilización..., ed. cit. Cap. VII.

23 Marcuse, Herbert: L'homme unidimensionnel, ed. cit. pág. 244.

24 Marcuse, Herbert: Eros y Civilización..., ed. cit. pág. 164.

25 Mallet, Serge: L'idole des étudiants rebelles: Herbert Marcuse in Le Nouvel Observateur, $N^{\circ}$ 182, 8-14 mayo 1968, pág. 8. Este artículo ha sido traducido y publicado en una obra colectiva titulada Marcuse polémico, por la Editorial Jorge Alvarez, Buenos Aires, 1968, pág. 20. civilizacićn no consiste en el gas, el vapor o las plataformas de ferrocarril; consiste en la reducción de los rastros del pecado original". (26).

III

Pero estos planteamientos nos llevan bastante lejos. El Derecho no puede ser comprendido sin referencia a la sociedad. A su vez, la sociedad no es una estructura inmutable sino que, por el contrario, nos ofrece múltiples opciones; comenzando por la decisión entre mantener el orden existente o cambiarlo. Marcuse afirma que es posible encontrar un criterio objetivo -aunque válido sólo dentro de la circunstancia histórica- para escoger entre tales opciones. Y ahora descubrimos que un elemento fundamental en tal criterio consiste en el desarrollo integral del hombre, de sus necesidades y facultades. Por consiguiente, la evaluación -indispensable- del ordenamiento jurídico está orientada en última instancia por una concepción del hombre.

¿Cuáles son las bases de este "humanismo" de Marcuse? En principio, su punto de partida es el mismo que el de Marx: se trata de liberar al hombre, es decir, suprimir la alienación (27). El hombre es concebido como un poder, como una libertad, que tiende a expansionarse, a alcanzar esferas cada vez más amplias de acción, a "humanizar" o someter a control humano un mayor número de relaciones. Es así como el hombre conquista la naturaleza y se hace cada vez más "sujeto", se afirma a si mismo como ser creador y determinante de sus circunstancias. Reencontramos en Marcuse la línea personalisia que ha sido antes esbozada por numerosos pensadores, aún cuando haya merecido diferentes desarrollos. Marcuse retoma la afirmación kantiana que se encuentra en el origen de todos los planteamientos humanistas contemporáneos, en el sentido que la verdadera libertad consiste en la posibilidad del hombre de realizar su existencia como un fin en sí mismo y no como un simple medio para otro fin; ser hombre es ser uno mismo y no otro (28), es luchar contra la "objetivi-

26 Marcuse, Herbert Eros y Civilización..., ed. cit. pág. 164.

27 Marcuse, Herbert: Libertad y agresión en la sociedad tecnológica, in La Sociedad Industrial contemporánea, obra colectiva, México, 1967, Siglo Veintiuno Editores S.A. pág. 61.

28 Ibid. pág. 61 . 
zación" o "cosificación". Es en este sentido que podemos afirmar que el hombre es pluridimensional (29), porque está en aptitud de abrir múltiples perspectivas, porque la libertad es siempre sinónimo de creación, de negación, de espontaneidad y supone el paso más allá de los límites. En una palabra, se trata de promover un hombre autodeterminado: "... si este cambio (cualitativo) pudiera establecer la autodeterminación como base misma de la existencia humana, especialmente en el campo del trabajo necesario, constituiría la revolución más radical y más completa de la historia" (30). El principio de la autodeterminación como base de la existencia significa no solamente la victoria sobre la naturaleza que se traduce en progreso material sino además $-\mathrm{y}$ sobre todo- que todo hombre no se encuentre sometido sino a sí mismo: así, la autodeterminación se opone radicalmente a todo tipo de autoridad externa o paternalismo como también a la determinación impersonal que lleva a cabo un mundo totalmente cosificado - "sociedades sin padre", las denomina Marcuse (31) - que establece los límites y canales del desarrollo de los intereses y necesidades del hombre (32).

El elemento original del "humanismo" de Marcuse radica en el replanteamiento de esta filosofía de la liberación o desalienación, a la luz del psicoanálisis freudiano. Afirma Marcuse que esta libertad esencial en el hombre no es un mero surgimiento sin orden ni concierto, sino que se orienta hacia la obtención de un estado de quietud que se encuentra en el origen de la vida y al cual ésta tiende a regresar enriquecida por las deierminaciones sucesivas que se ha ido formulando en tanto que liberiad. Por consiguiente, la libertad debe ser entend:da como auto-realización, como una aspiración a la plenitud que no puede ser nunca colmada, pues libertad supone siempre movimiento continuo, opciones no realizadas, una cierta forma de carencia. Sin embargo, cabe pensar oiro camino opuesto al descrito para obtener la quietud: ésta se lograría igualmente por la total indeterminación, por la supresión de todas las determinaciones, por la eliminación. Entonces, la quietud puede ser alcanza-

29 Marcuse, Herbert: El envejecimiento del psicoanálisis, in Marcuse polémico, ed. cit. pág. 39.

30 Marcuse, Herbert: L'homme unidimensionnel, ed. cit. pág. 69 .

31 Marcuse, Herbert: El envejecimiento del psicoanálisis, ed. cit. pág. 51.

32 Ibid. págs. 51 y ss. da por la plena gratificación o por la plena destrucción. Pues bien, a estos dos caminos corresponden dos tendencias que conforman la estruciura psíquica del ser humano: el instinto de la vida y el instinto de la muerte, Eros y Tanatos. Es asi como Eros es la potencia vital, es la libertad autodeterminándose a cada instante, es el amor en su sentido más amplio como tendencia a combinar la vida en unidades cada vez mayores, a enriquecer la libertad. La satisfacción de esta tendencia (gratificación) produce placer. En cambio, Tanatos constituye la fuerza destructiva, la agresividad que puede ser dirigida contra el propio sujeto, contra la naturaleza o contra los demás sujetos (33). Recordemos que Erich Fromm había destacado la existencia de tendencias sociales de tipo sadomasoquistas que explican ciertas formas de organización o conducta colectivas (34). Pues bien, la desalienación, según Marcuse, consiste en conformar la vida en función del principio del placer, liberar los impulsos eróticos y reducir la agresividad. Pero, notémoslo bien, Marcuse distingue entre lo que él denomina el concepto inicial de la sexualidad en Freud y el Eros como instinto de la vida (35). Por eso, cuando Marcuse se refiere a Eros, placer, erotización del mundo, etc. no pretende propugnar una libertad sexua! desenfrenada como pauta de conducta social sino un acceso a esferas superiores de autorrealización o personalización integral. Incluso, tiene reflexiones muy críticas sobre el incremento de la sexualidad en los últimos años: afirma que ésta no es sino una manifestación más del estado represivo de la sociedad; la expansićn del instinto de la vída (erotización) que debía realizarse en todos los órdenes de cosas ha sido sustituida por una mera expansión hipertrofiada de la sexual:dad genital que consolida la represión general al actuar como válvula de escape de las fuerzas auténticamente liberadoras (36). La hipersexualidad genital actual corresponde no a una liberación sino a una represión del Eros en todos los aspectos no genitales: la vida del trabajo rutinario, la falta de armonía entre el hombre y el ambiente, la falta de placer general, lleva a una exacerbación del único aspecto libre que es el genital. Así esta hipersexualidad es sig-

33 Marcuse, Herbert: Eros y Civilización..., ed. cit. págs. 37 y ss.

34 Fromm, Erich: El Miedo a la Libertad. Buenos Aires, 1966. Ed. Paidós S.A. Cap. V.

35 Marcuse, Herbert: Eros y Civilización..., ed. cit. pág. 38.

36 Ibid. págs. 55, 63, 95, 106 - 7, etc. 
no de represión y su aparente libertad contribuye a enmascarar la opresión (37). "En contraste, el libre desarrollo de la líbido transformada dentro de instituciones transformadas, al tiempo que erotizaría zonas, tiempo y relaciones convertidas en tabús, minimizaría las manifestaciones de la mera sexualidad integrándolas dentro de un orden mucho más amplio, incluyendo el orden del trabajo". (38)

Ahora bien, el hombre constituye en sí mismo un todo pero no vive aislado; aún más, su vida es en cierta forma producto y causa de una totalidad mayor constituida por la sociedad. Para Freud, la organización social es simplemente la forma de reprimir colectivamente los instintos bésicos del hombre que, dejados en liberiad, actuarian egoístamente e impedirian su propia autorrealización; la restricción operada por la sociedad a través de sus múltiples mecanismos (Derecho, Moral, Cultura, etc.) es la precondición esencial del progreso (39). En cambio, Marcuse sostiene que esta interrelación entre sociedad y represión es sólo el producto de una organización histórica específica de la existencia humana y que cabe pensar en una organización social erótica, es decir, no represiva. Si admitimos la existencia de Eros como impulso creador y autodeterminante, la definición freudiana de este instinto -como la tendencia a integrar unidades cada vez mayores y llevar la vida a un desarrollo más alto- cobra un nuevo significado: el impulso biológico llega a ser impulso cultural (40). También “Eros lucha por 'eternizarse' a si mismo en un orden permanente" (41). Pero, aun cuando aceptemos la posibilidad de la expansión libre de Eros hasta constituir una sociedad erótica, ¿qué podemos pensar de Tanatos? ¿No debemos suponer, acaso, que la liberación de los impulsos básicos del hombre conducirá también a un desarrollo del instinto de agresividad? En otras palabras, la liberación del hombre puede llevarnos al bien o al mal, al amor o al odio, al desarrollo de una vida más alta o a una mayor presencia de la muerte bajo todos sus aspectos: agresividad, destrucción, fatiga, explotación, etc. ¿No será, entonces, necesaria una represión al menos del instinto de la muerte que todo hombre lleva consigo? Marcuse no acepta esta alternativa. Afirma que las tendencias egoistas y agresivas se desarrollan en virtud de la escasez de

37 Ibid. pág. 212.

38 Ibid. pág. 210. El subrayado es de Marcuse.

39 Ibid. págs. 19, 27, etc.

40 Ibid. pág. 218.

41 Ibid. pág. 229. los bienes necesarios para satisfacer las necesidades del hombre; en cambio, en un mundo de la abundancia que la capacidad productiva actual del hombre permite avizorar, la agresividad quedaría reducida al minimo (42). Como ya lo habia observado antes Fromm, si el hombre puede realizar su yo plenamente y sin limitaciones, habrán desaparecido las causas fundamentales de sus tendencias impulsivas antisociales (43). Además, también Fromm había afirmado que "el impulso de vida y el de destrucción no son factores mutuamente independientes sino que son inversamente proporcionales... cuanto más plenamente se realiza la vida, tanto menor es la fuerza de la destructividad"' (44). Marcuse retoma esta linea de pensamiento para defender la posibilidad de avanzar hacia una sociedad no represiva en la medida que liberemos el instinto de la vida; las relaciones entre Eros y Tanatos son históricas y la agresividad puede ser vencida (45). Indudablemente, dado que la abundancia o satisfacción total es imposible y que la realidad siempre condiciona y limita en cierta forma el ejercicio de la libertad, existirá también siempre un cierto nivel de represión. Sin embargo, Marcuse distingue entre la "represión básica" y la "represión sobrante": La primera únicamente ajusta los impulsos a las posibilidades concretas que permiten las circunstancias para ejercer la libertad sin peligro de perderla; la segunda, en cambio, impone restricciones adicionales a las necesarias en beneficio de un grupo o en aplicación de una idea abstracta, muchas veces inconsciente (46). La represión básica procura conservar la espontaneidad y facilitar el placer y la autodeterminación; no constituye propiamente una limitación sino que permite una mayor expansión de Eros. Si un niño quiere cruzar la calle en medio de los automóviles, la represión de esta "'necesidad" no es represiva de las potencialidades humanas. $Y$ este mismo tipo de "represión no represiva" es el que configura la autoridad del ingeniero, del piloto de un avión en vuelo o del policía de tráfico (47). En la misma forma podríamos decir que si un grupo social en un país sub. desarrollado busca niveles de consumo similares a los de los países desarrollados en perjuicio de la tasa de

42 Ibid. págs. $143-4,229-30$.

43 Fromm, Erich, ob. cit. pág. 314.

44 Ibid. pág. 222.

45 Marcuse, Herbert: Eros y Civilización..., ed. cit. págs. $91-3,150$.

46 Ibid. págs. $50-2$.

47 Ibid. pág. 231. 
capitalización factible del país, su restricción no constituye una actitud represiva sino que posibilita una expansión de la libertad o de la "satisfacción erótica" para el conjunto de los hombres de tal país. Por el contrario, la represión sobrante no surge de la verdaderas necesidades de los hombres que componen una colectividad sino que se impone desde fuera sea por una autoridad personificada en un grupo o en un hombre, sea por pautas sociales anónimas que exigen una conformidad automática del individuo. Es importante señalar que para Marcuse son igualmente totalitarios los Estados policiales como las democracias cuando eliminan toda oposición global al sistema mediante la manipulación de las conciencias (48); en este último caso, la represión es interiorizada al punto que el hombre vive "libremente" su dom:nación (49). Puede decirse entonces que la represión básica es una manif́estación de Eros y, en cambio, la represión sobrante es la expresión de impulsos agresivos de los grupos dominantes o de impulsos autodestructivos de los hombres que temen a la propia espontaneidad creadora y buscan evadir la libertad cobijándose en la seguridad pasiva del conformismo impersonal.

\section{IV}

Marcuse sostiene que la sociedad puede organizarse de manera que la represión sobrante sea desterrada y que la represión básica tienda a ser cada vez menor. Dentro de este orden de ideas, cabe imaginar los perfiles de una nueva sociedad en la que el hombre se realizará plenamente, en la que toda alienación habrá sido suprimida y en la que el ser humano se encontrará conciliado consigo mismo, auténticamente libre, creador de su propia historia y único responsable de su destino. Esta nueva sociedad estará caràcterizada, entonces, por el principio de autodeterminación: ninguna autoridad será aceptada si no emana de aquellos que serán gobernados por ella; ninguna norma será cumplida si no surge como decisión colectiva o como necesidad de las cosas mismas. Lo hemos mencionado anteriormente: la autodeterminación no pone en cuestión la competencia técnica ni subordina la aplicación de medidas en este campo a una apro-

48 Marcuse, Herbert: L'homme unidimensionnel, ed. cit. pág. 7, etc.; Libertad y agresión. .., ed. cit. pág. 53; El envejecimiento del psicoanálisis, ed. cit. pág. 40; etc.

49 Marcuse, Herbert: Eros y Civilización..., ed. cit. pág. 60 . bación previa; simplemente, encuadra la técnica dentro de un universo de fines preestablecidos y afirma que estos fines no pueden ser establecidos sino colectivamente. Por consiguiente, lo que se trata es de liberar la espontaneidad del hombre - de todo hombre- para determinar el sentido de su vida como parte de un todo social, barrer las estructuras rígidas que impiden que los hombres modelen colectivamente su destino histórico, suprimir los privilegios o las diferencias que permiten a algunos hombres empinarse sobre otros en esta tarea de creación de sentido.

Ahora bien, la autodeterminación del grupo social en tanto que tal está constituida por el ejercicio colectivo de la autodeterminación de cada hombre. En consecuencia, debe existir un cierto nivel de privacidad o independencia de cada hombre frente al grupo bajo pena de que la autodeterminación colectiva se desnaturalice. En efecto, si no se mantiene un cierto "espacio vital" de cada hombre en el interior de la sociedad, será imposible que éste pueda volverse sobre sí mismo, preguntarse por el sentido de la sociedad establecida, cuestionarlo y eventualmente modificarlo; habriamos tropezado con una nueva fuente de rigidez, con una nueva forma totalitaria de organización social en cuanto que limitaría la posibilidad de negar ese orden establecido (50). Es esto lo que Marcuse encuentra que ha sucedido con la civilización occidental: los valores colectivos predominantes se han impuesto de manera tan eficaz a través de los diferentes mecanismos de sugestión (como los medios de comunicación de masas), que la crítica sólo se concibe dentro del sistema y no del sistema como un todo. "Una sociedad que es incapaz de proteger al individuo privado, incluso en el interior de sus cuatro paredes - - "la casa ha sido invadida por la opin:ón pública y el dormitorio está abierto a las comunicaciones de masas (mass media)" (51) - ¿tiene el derecho de decir que respeta al individuo y que es en sí misma una sociedad libre? Es cierto, no puede decirse que una sociedad es libre porque ha tenido éxito -como realización fundamental- en lograr la autonomía privada. Sin embargo, si no existe autonomía privada, las instituciones de las libertades económicas y políticas más auténticas son puestas en duda; la libertad resulta negada en sus fundamentos ocultos" (52).

50 Marcuse, Herbert: L'homme unidimensionnel, ed. cit. pág. 268.

51 Ibid. pág. 45.

52 lbid. pág. 269. 
Claro está que todo lo expuesto implica además una verdadera "conversión" del hombre; para llegar a esta sociedad libre no basta con crear nuevas formas de organización sino que es preciso además crear un nuevo tipo de hombre, liberado de las tendencias regresivas interiorizadas en lo más profundo de su mente. No cabe duda que la libertad no puede consistir únicamente en la forma de expresión autodeterminada de la voluntad de los hombres sino en el contenido mismo de esta voluniad. Un grupo de hombres mentalmente esclavizados puede "libre" y "democráticamente" elegir a Hitler como gobernante; $y$, sin embargo, éste no sería un acto democrático (53). Por eso, dar todos los medios de expresión a la imaginación del hombre actual constituiría quizá una regresićn. "Los individuos mutilados (mutilados también en su facultad de imaginación) tenderian a organizar y a destruir aún más de lo que se les permite actualmente hacer. Esta liberación constituiría el horror absoluto - no el desanudamiento de la cultura sino el libre movimiento de sus tendencias más represivas" (54). Vemos así que la autodeterminación como procedimiento no basta para configurar una sociedad libre sino que se requiere además un cambio en el hombre mismo para que, mediante la autodeterminación, escoja siempre su libertad. Si en la actualidad la administración de las grandes Compañías quedara en manos de los obreros (autogestión), es posible que cambiarian las condiciones de trabajo, la distribución de las ganancias, etc.; pero, dice Marcuse, no se produciria un cambio político o social imporiante porque los obreros aceptan los mismos valores de la sociedad industrial contemporánea: solamente se producirian cambios radicales si los obreros aportaran metas y necesidades cualitativamente distinias (55), es decir, si se ha creado al hombre nuevo o si paralelamente se establecen los mecanismos para hacerlo.

Siguiendo este razonamiento, Marcuse afirma que es condición fundamenial para la realización completa de este hombre nuevo, que se elimine la alienación que se produce en el proceso productivo mismo. El hombre ha dividido su vida en dos partes: una en la que sus actividades son socialmente productivas, pero en la que prima la represión; otra en la que prima la libertad, pero que carece de significación so-

53 Ibid. pág. 142.

54 Ibid. pág. 274.

55 Marcuse, Herbert: Libertad y agresión..., ed. cit. pág. 64; L’homme unidimensionnel, ed. cit. pág. 276. cial. La primera está constituida por el tiempo de trabajo; la segunda, por el tiempo dedicado al esparcim:ento. Mientras trabajan, los hombres no viven sus vidas sino que cumplen roles sociales preestablecidos en algunos casos impersonalmente $y$ en otros por un grupo de intereses particulares. Este campo de la actividad humana se ha excluido de los deseos libres del hombre. "Su trabajo está al servicio de un aparato que ellos no controlan, que opera como un poder independiente al que los individuos deben someterse si quieren vivir" (56). Además, el trabajador no relaciona en forma directa su actividad con la satisfacción de una necesidad personal. Todo ello determina que la actividad productiva se manifieste como trabajo obligatorio, alienado y no placentero. En cambio, el tiempo que se destina a vivir libremente está limitado a aquellas actividades marginadas que no influyen sobre el todo social, tales como el arte, la poesía, las diversiones, la religión, etc. $Y$ lo que es más grave: se considera que esta división es fatal y que las actividades o tiempos dolorosos del hombre son indispensables para la obtención de una gratificación especializada en tiempos y actividades diferentes; la interiorización de este planteamiento da lugar a la "mística del trabajo" (57).

Marcuse señala que ya Marx habia denunciado esta alienacićn én el proceso mismo de producción, además de la alienación en cuanto a los frutos del trabajo. Pero -a diferencia de Marx- sostiene que esta alienación no puede superarse sino por la abolición del trabajo (58). Esta convicción radical se hace presente a menudo en las diferentes obras de Marcuse. Notémoslo bien; esto no significa que el hombre debe permanecer en la inactividad más absoluta, renunciar a sus conquistas sobre la naturaleza y vivir de una manera primitiva. Por el contrario, el hombre es actividad; sin ella se cosifica. En consecuencia, se trata más bien de que la actividad socialmente útil esté dirigida por la transparente satisfacción de una necesidad individual (59); es sólo en esta forma como constituirá la realización de un deseo humano y personal, conciliará al hombre consigo mis-

56 Marcuse, Herbert: Eros y Civilización..., ed. cit. pág. 60.

57 Ibid. pág. 60.

58 Marcuse, Herbert: Libertad y agresión..., ed. cit. pág. 61.

59 Marcuse, Herbert: Eros y Civilización..., ed. cit. pág. 217. 
mo y estará regida por la libertad. Es cierto que los pueblos primitivos cumplían en cierta manera esta aspiración pues, aun cuando primaba la escasez, su distribución todavia no era opresiva y el trabajo del hombre estaba directamente orientado hacia la satisfacción de necesidades evidentes (60). No puede pretenderse ahora una vuelta hacia esa etapa superada. Por otra parte, creer que el trabajo dentro de la sociedad tecnológ:ca puede desarrollar las facultades humanas "es una idea roméntica, un sueño de artesano" (61). Basta con pensar en el trabajo realizado por un obrero de una línea de montaje. En consecuencia, no cabe sino aprovechar las victorias de la técnica para suprimir el trabajo obligatorio mediante la superación de la escasez y la automatización general (62). La humanidad, en la etapa avanzada de su desarrollo en que nos encontramos, puede aspirar a una liberación de la necesidad de manera que su actividad no pese sobre ella como una esclavitud sino que se convierta en un juego (63). Observemos también aquí la pretensión de "borrar las huellas del pecado original" a que nos hemos referido antes.

En realidad, si las máquinas pueden hacer el trabajo necesario, la relación entre tiempo libre y tiempo de trabajo habrá variado sustancialmente y los hombres podrán dedicarse en mayor grado a orientar la actividad colectiva impartiendo sentido a la praxis humana y personalizando la auiodeterminación colectiva en base a una auténtica autodeterminación individual. Cabe advertir que la atribución de un carácter lúdico a la actividad humana no significa que pierda su utilidad social y pase a ser un mero "entretenimiento" o diversión irresponsable; la distinción entre trabajo y juego está en el propósito y no en el contenido de la actividad (64). No se trata tampoco de instaurar el ocio como valor social sino de liberar la actividad. "Hay una enorme diferencia, dice Marcuse, entre tiempo de ocio y tiempo libre. El ocio es el tiempo sin trabajo o después del trabajo que aún se refiere en todos los aspectos al trabajo cotidiano, que se dedica a la recreación o al descanso, necesario por

60 Ibid, pág. 163.

61 Marcuse, Herbert: Libertad y agresión..., ed. cit. pág. 62.

62 Marcuse, Herbert: Eros y Civilización..., ed. cit. págs. 104-5, 203-4; L'homme unidimensionnel, ed. cit. págs. 60 y 255; Libertad y agresión..., ed. cit. págs. $83,88$.

63 Marcuse, Herbert: Eros y Civilización..., ed. cit. págs. $196,221-24$.

64 Ibid. pág. 222. las formas de trabajo enajenado a las que el hombre está atado todo el día. El tiempo libre no es tal cosa. El tiempo libre es algo más que el descanso, la recreación o la diversión; es el tiempo durante el cual el individuo puede ser él mismo y desarrollar autónomamente sus propias facultades y necesidades", (65). "La libertad debería estar localizada en el mismo mundo del trabajo técnico" (66).

Como puede apreciarse, Marcuse pretende construir con ayuda de la técnica moderna - pero en base a una decisión política previa, pues la técnica por sí sola puede conducirnos a una sociedad más totalitaria- la imagen de la sociedad soñada por Rousseau. Este filósofo describía como ideal social el sistema de las ciudades griegas en el que los ciudadanos no se ocupaban sino de política, es decir, de establecer los ínes sociales; y esta tarea se cumplía bajo el principio de la autodeterminación por el pueblo mismo, con la participación más directa de cada ciudadano: "el pueblo estaba sin cesar en asamblea sobre la plaza" (67). El problema de Rousseau estribaba en que para realizar esta democracia directa y esta libertad completa los griegos contabán con los esclavos a quienes no se consideraba parte del pueblo y cuyo trabajo permitía la liberación de tiempo indispensable para que los ciudadanos se ocuparan de la política. "¿Qué!", se pregunta Rousseau, "¿la libertad no se mantiene sino con el apoyo de la esclavitud?" y no sabe qué contestar pues ha planteado como postulado básico que no puede tolerarse la esclavitud de ningún hombre. Sin embargo, no deja de reconocer que la liberacićn de los esclavos nos lleva inevitablemente a la instauración del trabajo obligatorio y a la alienación del hombre que se produce como consecuencia: "Ustedes, pueblos modernos, ustedes no tienen esclavos pero son esclavos por sí mismos; han pagado la libertad de ellos con la de ustedes" (68). Dentro del planteamiento de Marcuse, la liberación del trabajo se realizará mediante la automatización total. No serán ya los esclavos quienes soportarán la libertad de los ciudadanos sino las máquinas que permitirán la libertad de los hombres: se habrá restaurado la democracia griega sin necesidad de restaurar la esclavitud. Además, los medios de comuni-

65 Marcuse, Herbert: Libertad y agresión..., ed. cit. pág. 88.

66 Ibid. pág. 89.

67 Rousseau, Jean Jacques: Politique du Contrat Social ou Principes du droit politique, L.III, Cap. XV.

68 Ibid. L.III, Cap. XV. 
cación de masas - cuyo desarrollo ha sido tan prodigioso en los últimos años al servicio de la represiónpodrían ser utilizados dentro de una sociedad nueva para incrementar el diálogo, para expansionar el debate público a un nivel mayor que el de la ciudad, a un nivel que supera la asamblea permanente sobre la plaza hasta alcanzar las dimensiones de la humanidad.

Esta nueva sociedad, fundamentada en la expansión de la libertad, conllevará no solamente la conciliación del hombre consigo mismo -en la medida que amplía cada vez más la esfera de la autodeterminación $y$, consecuentemente, atribuye mayor responsabilidad al hombre sobre su propio destino; la esencia del hombre es su libertad y, por eso, conciliar al hombre consigo mismo es devolverle su poder de decisión- sino que también implicará la conciliación de los hombres entre sí y del hombre en general con la naturaleza. Marcuse anuncia la posibilidad de que el paraíso pueda darse de nuevo en la Tierra, pero esta vez sobre la base de los logros de la civilización (69). En este estado, los hombres gozarán del placer que produce la actividad libre y espontánea y, a su vez, esta "erotización" (o liberación del instinto de la vida) originará una reducción de los instintos agresivos: los hombres podrán vivir en paz. La actividad del hombre sobre la naturaleza no tendrá por objeto orientarla hacia fines de destrucción sino, por el contrario, hacerla participar de la vida y de la libertad incorporándola a un mundo auténticamente "humano", dignificándola al convertirla en colaboradora del placer "erótico". En una palabra, se trata de construir una sociedad que viva según las reglas del arte, que sea libre en su actividad como lo es la actividad artística y que considere la naturaleza como el material para realizar la obra de arte de vivir. La naturaleza, objeto del trabajo -entendido éste ya como actividad libre-, no se toma como objeto de dominación y explotación sino como un "jardín", con la misma connotación de amor, juego y placer que implica un jardín o una huerta (70). Por eso Marcuse acoge con entusiasmo el programa de vida enunciado por los surrealistas: "pratiquer la poésie" (71). Esto no significa que las discrepancias entre los hombres puedan suprimirse totalmente o que la naturaleza no ofrezca más resistencia a la actividad humana. Pero los con-

69 Marcuse, Herbert: Eros y Civilización..., ed. cit. pág. 34.

70 Ibid. pág. 223.

71 Ibid. pág. 171. flictos, los antagonismos que pudieran existir no estarán basados en la represión del placer de la libertad sino en las diferentes formas de buscarlo (72). $Y$ la resistencia de la naturaleza será vencida para liberarla a su vez de la contingencia, el sufrimiento y la violencia (73) y llegar así a una consonancia placentera entre el hombre y la naturaleza bajo el primado de la libertad (74).

Dentro de la organización actual de la sociedad, solamente unos pocos hombres han logrado vivir libremente: los artistas, los bohemios, los aventureros, los intelectuales, la juventud, de un lado; los grupos que permanecen en estado primitivo, los artesanos quizá, los habitantes de países que aún no han ingresado al esquema de valores de las sociedades "desarrolladas" (sean capitalistas o socialistas), que no han acogido la "mística del trabajo" ni aceptado la lucha de la competencia (a escala individual, nacional o internacional), de otro lado (75). Sin embargo, todos ellos han readquirido o conservado su libertad recortando su esfera de acción; todos ellos son más o menos libres en función de una mayor o menor marginalización de la sociedad: la libertad no la obtienen a través de la sociedad sino fuera de ella. En esta forma, tal libertad no es auténtica puesto que si admitimos que el hombre es un ser social, esa libertad sólo se ha logrado mediante un recorte de su personalidad, mediante una marginalización respecto de algo que es esencial a su ser: se trata, pues, de una libertad aparente que esconde una alienación ya que no se basa en una reconciliación del hombre consigo mismo. Estos hombres son libres en la medida que han sido separados de los sectores más dinámicos y decisivos de la vida del grupo social; se les ha permitido vivir libremente dentro de una isla social constituida por un cierto tipo de actividad (los artistas), por su edad (la juventud), por el rezago en la evolución técnica (el anacrónico artesanado), por medios geográficos que establecen condiciones de aislamiento (tribus primitivas en regiones apartadas), etc. Una libertad "permitida" o basada en una "autorización" expresa o tácita, una libertad limitada por otras

72 Ibid. pág. 234.

73 Marcuse, Herbert: L'homme unidimensionnel, ed. cit. pág. 260.

74 Marcuse, Herbert: Eros y Civilización, ed. cit. pág. 176.

75 Ibid. pág. 182; L’homme unidimensionnel, ed. cit. pág. 10,280 ; Libertad $y$ agresión..., ed. cit. págs. $71,76$. 
libertades, no es verdadera libertad: solamente en la medida de que la libertad de cada hombre se identifique con la libertad de los demás, que el campo de acción de cada hombre sea similar al campo de acción de los demás, en una palabra, que la libertad de cada hombre se expansione hasta el punto de concordar con la libertad del todo social, solamente entonces se habrá logrado la auténtica libertad humana basada en la autorrealización plena del hombre.

Por eso, dice Marcuse, proponer simplemente que los hombres busquen a título individual esta consonancia placentera con la naturaleza y consigo mismo para que algunos logren ser libres a la manera del artista, constituiria un esteticismo irresponsable, un lujo incompatible con el estado de represión re:nante; en cambio, Marcuse propone concebir la función estética como el principo que gobierne toda la existencia humana y que sólo puede realizarse si llega a ser universal (76).

\section{V}

Efectuada esta breve revisión de las ideas sociales de Marcuse, es fácil advertir las notables consecuencias jurídicas que se derivan de ellas.

Ante todo, como lo hemos señalado en la primera parte de este artículo, la posición de Marcuse es de antipositivismo militante. Desde su punto de vista, la sociedad constituye un todo que no puede ser desvinculado en partes autónomas: no podemos decir que la Economía estudia una parte de lo social, la Sociología otra, el Derecho otra diferente y así sucesivamente. La sociedad está constituida por la praxis histórica de los hombres que la componen y que ofrece múltiples facetas (económicas, sociológicas, jurídicas, etc.) que a su vez condicionan diferentes aproximaciones a una misma problemática. Pero, siendo el campo de estudio el mismo y distinta solamente la perspectiva, cada una de las ciencias respectivas debe tener plena conciencia de su mutua dependencia respecto de las otras: ninguna de ellas puede pretender explicar por sí sola lo real. Dentro de esta orden de ideas, el positivismo jurídico, que por principio vuelve las espaldas a la realidad social, no puede coger lo real concreto y debe limitarse a constituir una ciencia formal; pero, como tal, se despo-

76 Marcuse, Herbert: Eros y Civilización..., ed. cit. pág. 197. ja de aspectos sustanciales de la realidad que estudia y queda así privada de sentido.

En consecuencia, es preciso confrontar el Derecho con la realidad social. Esto significa que la labor del jurista no debe reducirse a determinar si una norma es formalmente válida y a interpretar sus alcances de conformidad con la voluntad del legislador, cualquiera que ésta sea; por el contrario, el hombre de Derecho debe penetrar en el sentido social de los textos legales, comprobar la complejidad de las situaciones concretas y discutir el contenido mismo de las leyes a fin de analizar sus efectos en la realidad que será regida por ellas, reconocer los valores o intereses que la sociedad pretende estimular o proteger en el momento que se vive y darles cabida en el seno de leyes concebidas para otras situaciones o dentro de otros principios, en una palabra, realizar una interpretación verdaderamente creadora de Derecho y no simplemente explicitadora de la voluntad de un legislador que se presume único, coherente consigo mismo, omnisciente y absolutamente justo.

Todo esto ha sido dicho antes por otros autores $y$ Marcuse lo da por supuesto. La escuela sociológica del Derecho y, en especial, el llamado real:smo norteamericano han insistido particularmente que el Derecho está referido directamente a la vida -a la realidad social- y no exclusivamente a criterios lógico-formales. Pound, Holmes, Frank, destacan que las construcciones legales son meras abstracciones de la real:dad y que, como tales, son siempre imprecisas: sólo tienen un valor instrumental, como herramientas para lograr los fines que la sociedad se propone y a los cuales es preciso acudir para resolver los conflictos en última instancia. Pero la crítica de Marcuse al positivismo va aún más lejos: cabe la posibilidad de superar el positivismo jurídico mediante la inserción del Derecho en lo social pero caer en la trampa del positivismo sociológico. El jurista puede dirigirse a lo real concreto para buscar las pautas de solución de los conflictos de intereses; pero este real concreto puede ser entendido simplemente como la realidad inmediata, como la realidad actualmente presente, como el dato social que adquiere valor de norma. En esta hipótesis, la sociedad resulta concebida como un estado definitivo que asegura su estabilidad imponiendo a través del Derecho las bases esenciales del sistema. Si en el caso del cositivismo jurídico las leyes se presentaban como dato irrefutable cuya evaluación se escapaba de las manos del jurista, en el caso del positivismo sociológico es el 
sistema de valores sociológicamente predominante en una sociedad determinada el que adquiere el carácter de dato irrefutable que no permite discusión alguna por el jurista: el hombre de Derecho se limita a aplicar por los canales jurídicos un determinado orden social "querido" por sus integrantes, se limita a establecer los "deseos sociales" y asegurarlos imperativamente. Marcuse denuncia en esta teoria una nueva forma de totalitarismo encubierta por un ropaje de libertad democrática. Nuevamente, la realidad es vista bajo una sola dimensión -la de su existencia inmediata- sin tener en cuenta que la auténtica espontaneidad implica siempre un poder de negación y que entendida así la libertad, las alternativas de camb:o que se ofrecen ante cada situación son múltiples: para Marcuse, toda sociedad conlleva en sí misma los principios de su propia destrucción y las bases de la sociedad futura; pero, a su vez, este mecanismo de transformación continua no está sujeto a determinismo alguno sino que depende del ejercicio de la libertad del hombre (77). Ahora b:en, si el hombre ha sido educado para la libertad, sus actos libres estarán orientados a expansionarla, a hacerse a si mismo cada vez más autodeterminante; en cambio, si el hombre ha interiorizado la represićn, su propia "libertad" lo llevará a acogerse a todo tipo de paternalismos, a entregarse en manos de hombres fuertes o de organizaciones sociales despersonalizadas donde la autoridad se ha encubierto en el anonimato. Marcuse ha denunciado que el hombre actual está condicionado (78), ha sido objeto de una dominación lo suficientemente efficaz como para "querer" todo aquello que contribuye a conservar el status actual (79). Este condicionamiento se produce a través de los medios de comunicación de masas y otros factores más sutiles (80). Incluso los productos mismos, los artículos de consumo, endoctrinan y condicionan al punto que logran modelar una falsa conciencia insens:ble a lo que tiene de irracional el mundo actual (81); ayudados por la publicidad, convencen al hombre medio que ahora vive mejor que antes $y$ esto conduce a una verdadera mimesis por la que el individuo se identifica inmediatamente con su socie-

77 Marcuse, Herbert: L'homme unidimensionnel, ed. cit. págs. $245-7$.

78 Ibid. pág. 33.

79 Ibid. pág. 33.

80 Ibid. pág. 33.

81 Ibid. pág. 37; Eros y Civilización. .., ed. cit. pág. 112. dad (82). En estas condiciones someterse a las mayorías por el hecho de ser tales constituye una renuncia a la libertad: las mayorias sólo pueden tener autoridad cuando están conformadas por decisiones netamente personalizadas y son expresión de la autodeterminación colectiva. Por eso, supeditar el Derecho a los deseos o convicciones de tal sociedad, constituir al "hombre medio" como pauta valorativa, es renunciar a la libertad bajo el pretexto de una falsa democracia, es identificar "lo racional" con "lo normal" frenando toda evolución más allá del sistema social vigente, cristalizando una sociedad represiva.

En esta forma, Marcuse parece haber regresado a posiciones en cierta forma semejantes a las del llamado Derecho Natural. En vía de reacción contra el positivismo, parece que surge nuevamente la diferenciación entre el "ser" y el "deber ser", entre el ser en acto y su perfección propia que se encuentra en potencia y que permite orientar este paso de la potencia al acto: el proceso de actualización readquiere su contenido axiológico. No todos los mundos posibles son valiosos sino sólo aquellos que responden a un criterio de perfección. Por otra parte, su crítica al determinismo -que en última instancia es una forma de positivismo- lleva a Marcuse a considerar este paso de la potencia al acto no como una sucesión mecánica e indefectible hacia el progreso sino como una verdadera opción entre el bien y el mal, entre to racional y lo irracional, entre lo conveniente y lo inconveniente: el "Tribunal de la Historia" no convalida los hechos anteriores por el sólo mérito de haber existido ya que tal concepción absolvería tocios los crímenes que se han cometido contra la humanidad (83). Hay, pues, que encontrar criterios que nos permitan conocer lo que es racional, lo que es bueno, lo que es justo. $Y$ éstos los hallaremos en la naturaleza del hombre, en la distinción enire lo que constituyen verdaderas o falsas necesidades humanas (84).

Sin embargo, esta similitud con las filosofias tradicionales es sólo aparente: se debe únicamente a que tanto Marcuse como la filosofía clásica admiten la posibilidad de difierentes eventualidades frente a cada situación e intentan introducir un criterio de selección entre ellas. Pero para Marcuse no existe una idea

82 Marcuse, Herbert: L'homme unidimensionnel, ed. cit. pág. 35.

83 Ibid. pág. 65 .

84 Ibid. pág. 66. 
predeterminada e inmutable de perfección, una noción ideal, absoluta, del hombre hacia la cual debamos orientar nuestros esfuerzos; nada más lejos del pensamiento de Marcuse que una Idea platónica de sociedad que deba ser realizada históricamente o que una definición de hombre de la que se derivan un haz de derechos subjetivos que la sociedad debe limitarse a proteger. Hemos visto que el hombre, según Marcuse, es fundamentalmente libertad: una libertad que coexiste constitutivamente con otras libertades (u hombres) y que, por consiguiente, sólo puede expresarse en el seno de ellas. En consecuencia, no solamente cada acto del hombre es libre sino que, a diferencia de las concepciones tradicionales, el destino o meta de estos actos también es libre, no está predeterminado ni siquiera en tanto que "deberser". En realidad, el "deber-ser" de la libertad es la libertad misma; el hombre en tanto que libertad debe ir escogiendo la libertad en cada opción, debe actuar de manera de acrecentar su campo de acción haciéndose cada vez más autodeterminante. Mientras que la justicia deniro de la filosofía clásica del Derecho Natural era la posibilidad de realizar socialmente una "idea" de hombre, para Marcuse es la posibilidad de realizar socialmente al hombre en tanto que libertad, es decir, en tanto que superación de todo esquema, de toda idea. Así, el progreso es la conquista voluntaria de mayores grados de decisión y responsabilidad, de una libertad que va redefiniendo a cada instanie las situaciones y los valores y frente a la cual nada es permanente, nada es inmutable.

Otra consecuencia importante de la aplicación de las tesis de Marcuse al Derecho estriba en que éste no tiene primordialmenie una función represiva de "control" de los impulsos egoistas del hombre sino más bien un carácter promocional, en el senido que tiende a contribuir a la liberación del hombre. Para toda una corriente del pensamiento jurídico que toma principalmente a Hobbes como punto de partida, la naturaleza del hombre se encuentra ya dada de una vez para siempre y no existe posibilidad de perfeccionar al hombre; esta naturaleza humana es concebida en términos de egoismo, agresividad, destructividad, etc.; por consiguiente, el papel del Derecho se limita a frenar al hombre para que no haga daño a los demés: el orden jurídico no tiene otro fin que hacer compatible el carácter explosivo de cada hombre con la existencia de una sociedad. Dentro de esta hipótesis, el hombre es también concebido como liber- tad; pero se trata de una libertad individual que tiende a desconocer las libertades de los demás sometiéndolas a su imperio. Ahora bien, si ésta es la naturaleza del hombre y si esia naturaleza es inmutable, el Derecho no puede perseguir otra finalidad que establecer barreras a la desbordante acción individual, señalar esferas de accićn en el interior de las cuales cada hombre pueda actuar a su antojo sin dañar a los demás, en una palabra, el Derecho tiene simplemente una función de dique o de represión.

Marcuse acepta que el hombre actual es egoista, agresivo y destructor. Pero estima que éstas son caracterísłicas históricas y que, por cons:guiente, el hombre es perfectible. Siendo asi, la libertad de cada hombre no debe realizarse estableciendo esferas de aislamiento sino, por el contrario, identificándose con la libertad de los demás mediante la participación mós intensa en las decisiones comunes. En consecuencia, dentro de las circunstancias actuales, el Derecho tiene también una misión represiva que cumplir respecto de los insiintos de agresión; sin embargo, su función atiéntica es promover los instintos de la vida, "liberar" la libertad y crear al hombre nuevo. Para Marcuse, el único camino seguro de contrarrestar la agresividad es alentando la "eróización" de la vida colectiva, expansionando la libertad: la mera represión no hace sino agregar una agresividad legal a la agresividad social. Deniro de este orden de ideas, el Derecho cumple un papel eminentemente pedagćgico; sus prescripciones son formas de enseñar a los hombres a ser cada vez más libres $y$, por consiguiente, a necesitar cada vez menos del propio Derecho. De esta manera, se resiablece el carécier fundamentalmente educacional que Platón atribuia a la ley.

El gran problema que se planiea enioncos es di de quién crea la ley o, dicho en otras palabras, quién educa a quién. Platón habla dado respisesta a esie interrogante afirmando que son los filósofos -quienes están más cerca del mundo de las ldeas- que educan a los no-filósofos; por eso, los reyes deben de converírse en filósofos o los filósoíos en reyes. Para Rousseau, la ley debe ser la expresión de la "voluntad general" y ésta es expresada por la totalidad de los ciudadanos. Pero cuando el pueblo no se encuentra aún suficientemente maduro o ha sido mentalmente esclavizado, la voluntad general puede no coincidir con la voluntad de todos; en este caso la voluntad general -que es la auténtica expresión de la libertad- será patrimonio sólo de los más lúcidos, de aquellos cuya mente y cuya voluntad no ha sido do- 
blegada por el servilismo. Marx consideró que confiar en hombres individuales era siempre introducir un factor subjetivo. Por eso prefirió buscar en la sociedad algún elemento que permit:era asegurar objetivamente la realización del interés general que, en el estado actual, no podía aún identificarse con el interés de todos o de la mayoria de los ciudadanos; es así como acudió al concepto de clase. Marx creyó encontrar una clase -el proletariado- que necesariamente perseguiría el interés general pues, al no poseer nada, no tenía tampoco interés particular alguno que defender: surge así la idea de la dictadura del proletariado y del Derecho como instrumento de realización de los valores de la clase proletaria, tesis que corresponde al afán educativo (en su sentido más amplio) a que antes hemos hecho referencia.

Marcuse comprende plenamente la dificultad. Afirma que es muy fácil burlarse del argumento sostenido por todos los teóricos de la "dictadura educacional" desde Platón a Rousseau e incluyendo al marxismo soviético, de que la inmadurez exige que la liberación sea impuesta por un grupo sobre otro; pero, en cambio, es muy difícil refutarlo (83). Ahora bien, nos dice Marcuse, "con toda la verdad que implica, este argumento no puede responder a la pregunta que se ha hecho más urgente con el tiempo: ¿quién educa a los educadores y dónde está la prueba de que ellos poseen 'el bien'?" (84). Y, sin embargo, el problema sigue en pie: en última instancia, son los propios individuos quienes deberian decidir cuáles son sus verdaderas necesidades; pero sólo en última instancia, cuando sean libres para dar su propia respuesta y no la respuesta estandardizada que, a través de los medios de comunicación de masas y hasia de los productos mismos, la sociedad industrial ha logrado imponer en las mentes de los individuos (85). En todo momento, nos encontramos, pues, con ese círculo vicioso de la liberación: para llegar a ser libres tenemos que previamente ser libres, para reconocer el valor de la libertad debemos ya haber trascendido la totalidad represiva establecida (86). ¿Cómo los individuos administrados - que son todos los hombres dentro de la sociedad industrial pues la administración de unos sobre otros es recíproca- cómo estos individuos que han perdido la espontaneidad, cuya imaginación ha sido mutilada, pueden liberarse a sí mismos? (87). En términos de la problemática jurídica, ¿quiénes pueden

85 Ibid. pág. 31 .

86 Ibid. pág. 247.

87 Ibid. pág. 274 . establecer las bases, los criterios, el sentido de un ordenamiento jurídico orientado a promover al hombre nuevo, orientado hacia la liberación del hombre? En realidad, es el concepto mismo de la democracia que ha sido puesto en cuestión con estos interrogantes. Dentro de un sistema formalmente democrático, la respuesta es relativamente simple: el sentido de la ley, los valores que ella vehicula, están determinados por las mayorías. Marcuse ha replanteado dentro de las condiciones actuales las objeciones formuladas por diversos filósofos: estas mayorías pueden encontrarse socialmente "pervertidas" y pretender más bien escapar al riesgo que implica siempre el ejercicio de la libertad, eludir su responsabilidad y buscar una tranquila seguridad en algún tipo de "esclavitud satisfactoria". Lamentablemente, Marcuse no nos da ninguna respuesta.

La aplicación de las ideas sociales de Marcuse al ámbito del Derecho implica además una devaluación de la Ilamada "seguridad jurídica". Para muchos tratadistas, la seguridad es uno de los fines primordiales del Derecho, al mismo nivel de la justicia. Así, por ejemplo, Radbruch considera que aún cuando el Derecho tiene una vocación de justicia, ésta es relativa y está sujeta a la diversidad de opiniones de los hombres; la seguridad constituye la respuesta a la positividad que exige el Derecho en tanto que mecanismo de ordenación de la vida (88), al punto que constiuye el primer tema del Derecho y deja en segundo plano a la Justicia (89). Dice Radbruch que "... en la imposibilidad de definir el Derecho justo, por esta razón, hay que conformarse, por lo menos, con estatuirlo, por medio de un poder que tenga, además, la fuerza necesaria para imponer lo estatuido. No es otra la justificación del Derecho positivo, pues la exigencia de la seguridad jurídica sólo puede ser cumplida mediante la positividad del Derecho" (90). Dentro de este orden de ideas, aun cuando pudiera pensarse que la "seguridad por medio del Derecho" (respeto de ciertos derechos o situaciones, tranquilidad pública, etc.) es ideológica $y$, por tanto, no esencial al orden jurídico, en cambio la "seguridad del Dere-

88 Lerner, Salomón: La idea del Derecho en la Filosofía Jurídica de Gustav L. Radbruch (tesis), Lima, 1968, pág. 38.

89 Ibid. pág. 46.

90 Radbruch, Gustav: Introducción a la Filosofía del Derecho, $3^{\text {a }}$ ed. México, 1965. Fondo de Cultura Económica, Col. Breviarios, pág. 39. 
cho mismo" constituye una de sus notas fundamentales (91). Esta seguridad jurídica exigiría: (a) que el Derecho se halle estatuido en leyes; (b) que estas leyes o normas constituyan criterios ciertos y precisos; (c) que estas leyes o normas que componen el Derecho positivo no se hallen expuestas a cambios frecuentes; y (d) que la intervención del juez no implique la introducción de nuevos criterios de valor, es decir, que el juez se limite a comprobar el cumplimiento de las circunstancias de hecho que originan la aplicación de la norma (92).

Resulta indudable que la seguridad jurídica así entendida no ha sido característica de todos los sistemas de Derecho que han existido en la Historia e incluso un análisis de Derecho Comparado nos permitiría encontrar que aún hoy en día este concepto no es comprendido de manera similar por todos los ordenamientos juridicos. Platón proponía para su Estado Ideal que los filósofos-administradores realizaran un descubrimiento libre del Derecho frente a cada caso concreto sin sujeción a norma alguna (93). Por su parte, Aristóteles (94) y más tarde Santo Tomás (95), aun cuando reconocen que se requieren leyes para contrarrestar una posible parcialidad de los jueces, destacan con especial énfasis que el Derecho es siempre cambiante y la ley es obligatoria sólo en la medida que encarna la justicia. Es solamente con el establecimiento de la civilización burguesa, de tipo mercantilista, que la seguridad abandona su función subsidiaria de la justicia para ocupar el primer plano de la escena jurídica. El hombre, se piensa a partir del S. XVII, está motivado por el deseo de ganancia, que es preciso fomentar pues contribuye al bienestar general. Pero para ello debe constituirse un orden jurídico estable, que permita prever, que permita calcular las oportunidades que ofrece el futuro; esto exige que las leyes sean claras y que se cumplan indefectiblemente, que se respete la palabra dada: el contenido de estas leyes o contratos - su justicia o injusticia - no tiene tanta importancia como su permanencia y su aplicación indefectible. "Covenants

91 Ibid. pág. 40 .

92 Ibid. pág. 40

93 Villey, Michel: La Formation de la Pensée Juridique Moderne. Cours d'Histoire de la Philosophie du Droit 1961-1966, París, 1968. Ed. Montchrestien, pág. 24; véase también Kelsen, Théorie Pure du Droit, ed. cit. pág. 337.

94 Villey, Michel, ob. cit. págs. 52 a 59.

95 Ibid. págs. 129 a 132. without sword are but words", decia Hobbes (96). E incluso la noción de Derecho Natural -que conservan algunos justifilósofos como un acto de reverencia al pasado - es comprendida como un orden cerrado compuesto por un conjunto de derechos y deberes perfectamente definidos.

Las objeciones a este tipo de sociedad tienen repercusiones sobre la noción de seguridad jurídica. Marx considera que el Derecho se limita a ésta y, por ese motivo, lo acepta durante la dictadura del proletariado a fin de asegurar la implantación de las nuevas estructuras sociales; pero, una vez instaurada la sociedad comunista y abandonado el estímulo económico, la seguridad juridica será innecesaria, los motivos de conflictos habrán desaparecido y el Derecho habrá perdido sentido. Desde un punto de vista bastante diferente, un grupo de juristas -especialmente Kantorowicz y Ehrlich- consideran que el endiosamiento de la seguridad impide que el Derecho siga de cerca a la realidad en la riqueza de sus combinaciones; como reacción, crean la llamada Escuela de Derecho Libre y proponen una interpretación judicial basada en una referencia directa a la justicia (freie Rechtsfindung). Desde el campo del psicoanálisis, la seguridad también fue objeto de ataques. Erich Fromm sost:ene que el deseo de seguridad del hombre moderno que lo lleva a buscar la mayor estabilidad social, a ampararse en normas incontrovertibles, a confiar en las decisiones "técnicas" de la autoridad, a adoptar una actitud de conformismo automático con lo que piensan las mayorías o el "hombre normal y corriente" $y$, en general, a huir de toda intervención responsable, no es sino un mecanismo de evasión, una manifestacićn masoquista que encuentra placer en perder su libertad a cambio de protección por el "leader", el partido o la sociedad de masas despersonalizadas; en última instancia, la seguridad jurídica se reduce a un "miedo a la libertad" (97). Y Jerome Frank —uno de los nombres más prestigiados del realismo jurídico norteamericano- afirma: "La ley siempre ha sido, es ahora y seguirá siendo, ampliamente vaga y variable. ¿Y cómo podría ser de otra manera? Aún en las sociedades relativamente estáticas, los hombres nunca han sido capaces de construir un conjunto cerrado de reglas eternizadas... ¡Cuánto menos posible es tal sistema legal congelado en los tiempos

96 Cit. p. Villey, ob. cit. pág. 699: Las convenciones sin la espada no son sino palabras.

97 Fromm, Erich: El Miedo a la Libertad, passim. 
modernos! Cuando las relaciones humanas están siendo transformadas diariamente, las relaciones legales no pueden ser expresadas en una forma rígida"' (98). Y para explicar el anhelo de un Derecho seguro que existe actualmente, Frank acude también a la idea de miedo a la autodeterminación creadora, a la idea de una necesidad infantil de un padre que proteja a sus hijos y decida por ellos: "La Ley -un cuerpo de reglas aparentemente caracterizado por la determinación iníalible de lo que es correcto y lo que es equivocado y por la decisión sobre quién debe ser castigado por sus fechorías - inevitablemente se convierte en sustituto parcial del Padre-Juez-Infalible" (99).

Las tesis de Marcuse resultan también en cierta forma incompatibles con la seguridad juridica. Sus ideas conducen a la instauración de una sociedad en la que todo hombre tenga el carácter de sujeto, en la que todo hombre sea un auténtico creador. Esta concepción deriva en un antipositivismo radical y en la posibilidad de mantener los derechos de la crítica y de la participación a todos los niveles: se trata de implantar un orden social basado en la espontaneidad, en la intervencićn personalizada de todos los miembros que integran el grupo social. Todo ello parece a primera vista incompatible con un sistema jurídico basado en un cuerpo cerrado de leyes que se resisten al cambio, que esiablecen de antemano todas las reglamentaciones y que, en consecuencia, no tienen la flexibilidad necesaria para admitir en cada momento la participación creadora de quienes están sujetos a ellas: la ley resulta así emanada de la voluntad de un legislador abstracto y se enfrenta a los hombres como una autoridad externa, incontestada, frente a la cual la única actitud vélida es la sumisión. La lendencia personalista que vive en la filosofía social de Marcuse no se compadece con una aplicacićn judicial meramente mecánica de textos legales pre-establecidos. En una palabra, los criterios de seguridad jurídica considerados indispensables por Radbruch, aparecen más bien como un obstáculo dentro del sistema social propuesto. Notemos bien que este menosprecio de la seguridad juridica resulta aún más radical en Marcuse que en la filosofía clásica del Derecho: ésta asignaba a la seguridad un papel subsidiario para asegurar la justicia; pero Marcuse considera que la justicia no es sino la implantación de la libertad crea-

98 Frank, Jerome: Law and the modern mind. New York, 1963. Anchor Books, Doubleday and Co. Inc. pág. 6.

99 Ibid. pág. 19. dora, lo que modifica a su vez totalmente las relaciones entre ésta y la seguridad al punto que pueden ser entendidas como conceptos antagónicos. Dentro del pensamiento aristotélico-tomista, expresado si cabe con terminología de Scheler, podríamos decir que la justicia es el valor fundante y la seguridad el valor fundado. Empero, al plantear la justicia como participación creadora, como libertad, como posibilidad de revisión permanente $y$ de autodeterminación libre, se introduce un elemento de plasiicidad en el seno mismo del sistema de valores que altera totalmente sus respectivos roles convirtiendo en antagónico el valor fundado.

Sin embargo, el problema no es simple: los conflictos entre justicia (libertad) y seguridad no pueden ser solucionados mediante la eliminación de la seguridad puramente. Si tal fuera el caso, ¿cómo aseguraríamos la propia libertad? ¿Cómo preservar ese "espacio vital" que establece la distancia entre hombre y sociedad necesaria para evitar una identificación que haría imposible toda critica? Es indudable que una organización social que se propone instaurar el reino de la libertad y de la creación, exige que las leyes sean lo suficientemente amplias y generales como para permitir una gran maleabilidad del sistema y una mayor participación responsable a todo nivel; ello supone también una administración de justicia bastante f́lexibie como para seguir de cerca esta permanente creación de sentido frente a cada circunstancia concreta. Pero hemos visto que los hombres pueden libremente escoger la negación de su propia libertad. $Y$, por otra parte, los jueces, las jerarquias administrativas $y$, en general, las autoridades sociales pueden constituir un poderosís:mo equipo totalitario si adoptan libremente decisiones negacioras de la libertad en base al ejercicio de un amplio poder discrecional. Es perfectamente conocido que fórmulas tales como la "buena fe", la adecuación a "la moral y a las buenas costumbres", etc. pueden ser utilizadas en vía de interpreiación para someter a los disidentes a las reglas y valores del grupo, cuando no son utilizadas directamente como instrumentos represivos exentos de todo control o limitación. En consecuencia, parecería necesaria una cierta limitación de la plasticidad en la regulación social precisamente para asegurar la continuidad de la propia plasticidad. Frente a este razonamiento, no es válido oponer la tesis de que la expansićn de los instintos de la vida (libertad) reducirá la vigencia de los instintos de agresión y eliminará así el problema de "asegurar la libertad": aun aceptando 
esta tesis, no cabe duda de que existirá un periodo de transición hasta la aparición del hombre nuevo, de la sociedad nueva, durante el cual la libertad estará siempre en peligro por motivo de la libertad misma. Dentro de la línea de pensamiento de Marcuse y parafraseando sus expresiones, podriamos responder a esta objeción afirmando que no se trata de eliminar la seguridad jurídica en general sino solamente la "seguridad sobrante"; permanecerá, en cambio, la exigencia de una "seguridad necesaria" que es aquella estrlctamente indispensable para mantener la libertad misma en el interior de las circunstancias históricas concretas. Aplicando las tesis de Marcuse, esta "seguridad necesaria" no presenta, pues, un contenido invariable sino histórico e inciuso tiende a disminuir: la aparición de un nuevo sujeto histórico (100) que pueda vivir espontáneamente su libertad en la misma forma como el hombre actual vive espontáneamente su represićn, hará innecesario asegurar juríd:camente la plasticidad, sino que ésta será auiogenerante. Marcuse ha señalado especialmente este problema desde el punto de vista político: "La autodeterminación será efectiva cuando no existan masas sino individuos liberados de toda propaganda, de todo endoctrinamiento, de toda manipulación, que serán capaces de conocer y comprender los hechos, de evaluar en fin las soluciones posibles" (101). Por el momento, según el grado de desarrollo político, pueden darse numerosas combinaciones entre la democracia directa y la autoridad centralizada; jurídicamente hablando, entre la libertad de creación de normas de Derecho y el aseguramiento legal de tal libertad.

\section{VI}

No es posible, dentro de los límites de un aríículo, revisar todas las consecuencias de las ideas de Marcuse con relación al Derecho. Baste señalar como especialmente significativa desde el punto de vista jurídico su tesis de que las libertades públicas que existen en el interior de un sistema represivo no constituyen sino negaciones inofensivas del sistema -al igual que formas "pintorescas" de protesta, como el modo de vida "beatnik", el budismo zen, etc. (102)que contribuyen a establlizarlo enmascarando la opresión con una apariencia de libertad (103). También ca-

100 Marcuse, Herbert: L'homme unidimensionnel, ed. cit. pág. 276 .

101 Ibid. pág. 275. be hacer presente, de manera especial, sus afirmaciones en el sentido que la libertad de expresión y la libertad de conciencia - como todo otro derechodeben ser confrontadas con la realidad social en que se vive para apreciar su vigencia efectiva; en ese sentido, mal puede llamárseles "libertades" cuando se ejercen solamente en el interior de un universo cerrado, condicionado por la propaganda, uniformizado masivamente con la ayuda de los medios más sutiles (104). Son importantes también sus observaciones sobre la teoría del mandato y la teoría de la competencia como explicación del alcance de los derechos electorales; hasta qué punto estos derechos protegidos por las leyes constituyen realmente un "proceso de consentimiento" y no un "proceso de manipulación". (104). En cada caso, Marcuse nos propone no limitarnos al examen del Derecho desde un punto de vista restrictivamente jurídico sino que, a partir de un valor que preside todo análisis (la libertad entendida como participación credora), confrontemos la formulación teórica de los derechos y obligaciones jurídicas con su vigencia social efectiva en el seno de una sociedad dada.

Nadie duda que todas las tesis expuestas son altamente controvertibles, ni que exigen una mayor precisićn. Existe ambigüedad en la concepción que Marcuse tiene del hombre, centrada sobre las nociones de placer y libertad que merecen un desarrollo más amplio y minucioso a fin de conocer su contenido con más exactitud. Por otra parte, la vieja oposición entre el individuo y la sociedad no ha sido resuelta: aun cuando en general se advierte en todo momenio una defensa de la individualidad similar a la de los movimientos personalistas, no se comprende fácilmente su realización en el interior del grupo social; en algunas ocasiones, pareceria que el grupo se desintegra en favor del individuo $y$, en otras, el individuo desaparece frente a las exigencias de la sociedad. Es así como, al menos durante el periodo de instauración de la "nueva sociedad", se daría una coexistencia insostenible entre elementos aún antagónicos. En la práctica, la resolución de esta contradicción puede conducir sea al triunfo del liberalismo individualista que neutralizaría el proceso de liberación para conservar las cosas en su estado actual, sea al triunfo del autoritarismo que haria imposible la libertad mediante una uniformización política terrorista. Asimismo, las nociones de "represión necesaria" y "represión sobrante" requieren un análisis cuidadoso a fin de evitar que se restablezca en vía de "represión necesa- 
ria" alguna nueva forma de autoritarismo: no podemos olvidar la lección del stalinismo que nos enseña cómo bajo el pretexto de las exigencias de la liberación (industrialización, cambio hacia estructuras más humanas, dictadura pedagógica para formar el hombre nuevo, etc.) pueden instaurarse sistemas sociales altamente represivos. Dentro de este orden de ideas, el Ilamado "círculo vicioso de la liberación" -que constituye un problema central de la política (¿quién dirige el grupo social?) y del Derecho (¿quién establece el contenido de las normas?) - no encuentra en las ideas de Marcuse una solución satisfactoria: se necesita ser previamente libres para crear un mundo libre; y, a su vez, un mundo libre es precondición de la existencia de hombres libres. Marcuse comprueba que en el mundo actual la mayoria de los hombres han sido interiormente esclavizados; por consiguiente, las "mayorías", el sistema democrático formal, no puede conducirnos a la liberación. Pero tampoco acepta que existan individuos, grupos o clases sociales imbuidos de una misión profética que puedan constituirse en guías del rebaño mayoritario: la clase obrera ha demostrado que pierde su vocación de universalidad al llegar al poder y, en consecuencia, la "dictadura del proletariado" deviene, en el mejor de los casos, una nueva forma de paternalismo.

Por otro lado, Marcuse no nos propone un programa de gobierno; al igual que Marx con relación a la última etapa de la sociedad comunista, ni siquiera nos explica cómo estará organizada la sociedad no represiva: simplemente sabemos que será libre, que en ella no existirá represión. En realidad, es precisamente la consecuencia con sus propias tesis que le impide formular un "modelo" de sociedad ideal. Dado que ha propuesto la instauración del reino de la libertad - de la espontaneidad, Marcuse puede invitarnos a participar en la construcción del mundo nuevo pero no puede señalarnos cómo será ese mundo nuevo: esta tarea debe quedar a cargo de la libertad creadora de los hombres. Proponer de antemano un "modelo" de sociedad significaría pretender excluir de la acción creadora la determinación de la forma misma de sociedad a crearse. Por eso, quienes buscan un programa político, un catecismo, unas pautas fáciles o difíciles pero seguras de acción, quedan decepcionados. Con Marcuse estamos frente al vértigo del vacío, de la construcción total, de la plena responsabilidad del hombre que no puede contar con otro elemento "dado" que su propia libertad. No hay recetas, nada se nos da hecho. Marcuse se limita a invitarnos a ser creadores, a entregarnos a una dinámica que pone en cuestión todo y cuya orientación no puede ser señalada previamente sino que será establecida a cada momento del proceso. En el fondo, el pensamiento de Marcuse constituye un renacer del espíritu libertario del anarquismo, reformulado para nuestro tiempo.

Hemos dicho que no cabe duda que las tesis de Marcuse son altamente controvertibles; sin embargo, no cabe duda también de que son altamente estimulantes. A pesar de su ambigüedad, a pesar de su "catastrofismo", a pesar del extremo radicalis:mo que implica la bandera del "Gran Rechazo", en Marcuse nos encontramos planteada una problemática que convulsiona los esquemas prefabricados, que recoge las aspiraciones más profundas del hombre a una vida mejor y que exige la confrontación de estas aspiraciones con el estado de sociedad en que vivimos. $Y$ ese estado de sociedad no está constituido únicamente por lo "político" sino por todas las dimensiones del hombre: la Política, es cierto, tiene un lugar predominante; pero también el Derecho es en cierta forma "Política" y también lo es la ciencia y el arte y la economía. La Política está presente en el mundo de la universidad, en el mundo del trabajo, en el mundo de la publicidad; toda actividad humana presenta un contenido político. $Y$ es así cómo esta problemática social alcanza a los juristas y los obliga a una revisión en profundidad de su propia ciencia.

Claro está que en un mundo donde, en base a las justificaciones más diversas, se ha considerado como valores al sufrimiento, al dolor, al trabajo enajenado, a la resignación, al sometimiento a la autoridad externa, a la libertad entendida como retraimiento de las tareas sociales, en un mundo asi organizado, las nociones de placer, juego, participación, auto. determinación, espontaneidad, libertad creadora, presentan una carga subversiva; además, cuando se ha adoptado como base el criterio de la estabilidad, la confianza en la fecundidad de la acción es de por sí un acto revolucionario. Por eso, Marcuse ha sido muchas veces calificado - no sin razón- como un "agitador"- Sin embargo, ¿quién se ha atrevido a creer en el hombre, quien ha denunciado que el hombre moderno pierde su vida en ganarla, quién ha afirmado que el instinto de destructividad puede ser superado, quien ha tenido el valor de proponer la realización de una sociedad libre y solidaria, triunfadora de la naturaleza y al mismo tiempo en armonía con ella, simplemente por este hecho merece ser escuchado. 